


\section{DISCLAIMER}

This report was prepared as an account of work sponsored by an agency of the United States Government. Neither the United States Government nor any agency Thereof, nor any of their employees, makes any warranty, express or implied, or assumes any legal liability or responsibility for the accuracy, completeness, or usefulness of any information, apparatus, product, or process disclosed, or represents that its use would not infringe privately owned rights. Reference herein to any specific commercial product, process, or service by trade name, trademark, manufacturer, or otherwise does not necessarily constitute or imply its endorsement, recommendation, or favoring by the United States Government or any agency thereof. The views and opinions of authors expressed herein do not necessarily state or reflect those of the United States Government or any agency thereof. 


\section{DISCLAIMER}

Portions of this document may be illegible in electronic image products. Images are produced from the best available original document. 


\section{NOTICE}

This report was prepared as an account of work sponsored by the United States Government. Neither the United States nor the United States Energy Research and Development Administration, nor any of their employees, nor any of their contractors, subcontractors, or their employees, makes any warranty, express or implied, or assumes any legal liability or responsibility for the accuracy, completeness or usefulness of any information, apparatus, product or process disclosed, or represents that its use would not infringe privately owned rights.

This report has been reproduced directly from the best available copy.

Available frnm the National Technical Information Service, U.S. Department of Commerce, Springfield, Virginia 22161.

\begin{tabular}{cccccccccccccc}
\multicolumn{10}{c}{ NATIONAL TECHNICAL INFORMATION SER VICE PAPER COPY PRICES } \\
EFFECTIVE JAN. 1, 1976
\end{tabular}

For additional pages, add $\$ 4.50$ for each beginning 100 pages. Add $\$ 2.50$ per copy for foreign price.

Microfiche $\$ 3.00$ (domestic) $\$ 4.50$ (foreign). 


\section{INFRARED ANALYSIS TECHNIQUES FOR OIL IDENTIFICATION}

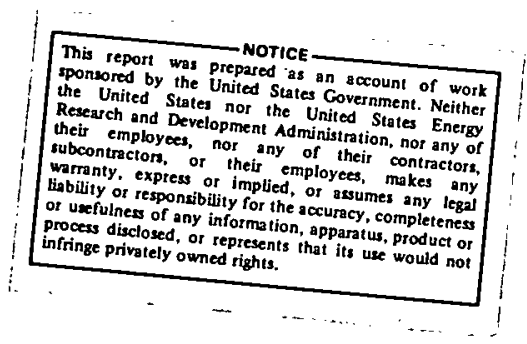

By

P. L. Grizzle and H. J. Coleman

Bartlesville Energy Research Center

Bartlesville, Oklahoma

Date Published-April 1977 


\section{THIS PAGE}

\section{WAS INTENTIONALLY LEFT BLANK}




\section{CONTENTS}

Page

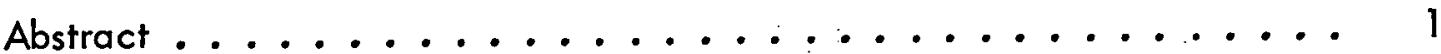

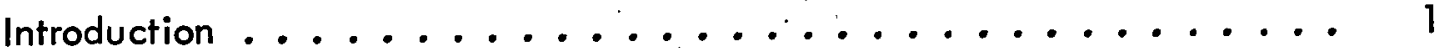

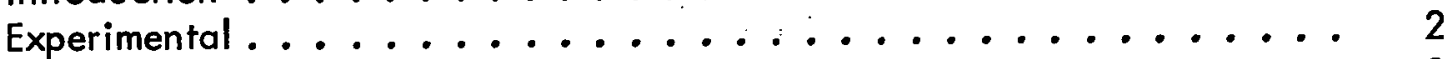

Crude oil and topped crude oil samples ............. 2

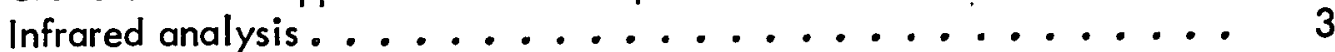

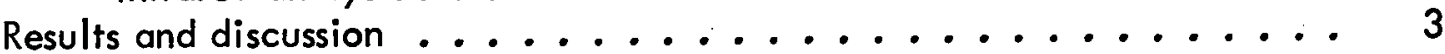

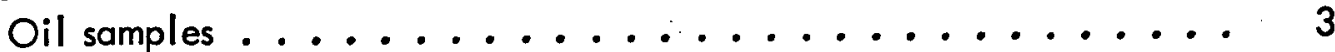

Selection of important analytical IR frequencies. ........ 5

Selective identification of similar crude oils ......... 11

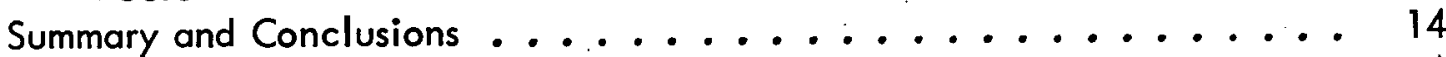

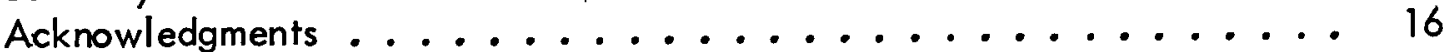

References....................... 17

\section{ILLUSTRATIONS}

1. Infrared transmission spectra for Haynesville, Lovisiana (75029) and Magnolia, Ohio (75003) crude oils. . . . . . . . . . .

\section{TABLES}

1. Source data for analyzed crude oils . . . . . . . . . . 4

2. Frequencies used in oil identification ............ 6

3. Evaluation of IR frequencies for fingerprinting crude oils ..... 8

4. Evaluation of IR frequencies for fingerprinting topped crude oils .. 9

5. Variations in IR absorbances between crude oils and corresponding topped crude oil samples ................ 10

6. Comparison of absorbance bands for crude oil 75066 to suspect crude oil samplos ........................ 12

7. Comparison of absorbance bands for crude oil 75059 to suspect crude

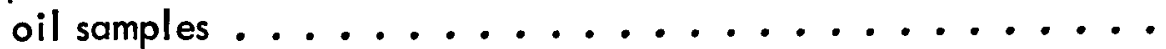

8. Comparison of absorbance bands for crude oil 75066 to topped suspect crude oil samples .................... . .

9. Comparison of absorbance bands for topped crude oil 75066 to suspect crude oil samples .................. 


\title{
INFRARED ANALYSIS TECHNIOUES FOR OIL IDENTIFICATION
}

By

P. L. Grizzle and H. J. Coleman ${ }^{2}$

\begin{abstract}
Infrared (IR) absorbance data at 14 selected frequencies were obtained for 52 crude oils and 52 corresponding topped (distilled through $275^{\circ} \mathrm{C}$ ) crude oil samples. Statistical analysis of the absorbance data justifies the use of 12 of these frequencies for the identification of weathered (topped) crude oils as well as unweathered crude oil samples. Detailed comparison of the $\mathbb{I R}$ absorbances at each frequency for 46 pairs of crude oils and corresponding topped crude oil samples indicates that, on the average, the magnitude of these bands will change by approximately 9 percent upon weathering and that changes as large as 21 percent can and, in general, will occur. Comparative absorbance data analysis of a group of artifically weathered and unweathered crude oil samples from a common geographical location indicates that spectrally similar unweather.' ed crude oils can be differentiated by $I R$ analysis. Results also suggest that unweathered reference crude oil samples should be artifically weathered by a consistently reliable weathering procedure before comparative analysis to a weathered spilled sample.
\end{abstract}

\section{INTRODUCTION}

With the continuing increase in crude oil imports and, hence, an increase in oil spills, the improvement of existing methodologies and the development and application of new analytical techniques for oil identification have become extremely important. Since no single analytical method has been developed which can uniquely characterize and, hence, identify each crude oil and related material, a multianalytical approach is required. The analytical methods commonly used include infrared (IR) spectroscopy $(\underline{1}, \underline{3}, \underline{5}, \underline{7-8}, \underline{20}, \underline{22}$, $\underline{23}, \underline{25-26}, \underline{36}, \underline{38}),{ }^{3}$ gas chromatography $(1, \underline{2}, \underline{5}, 12,16,18-19, \underline{21}, \underline{24}, \underline{29-32}, \underline{38-39})$, ul traviolet and fluorescence spectrophotometry $(1, \underline{5}, 10,15,17,28,37)$, mass spectrometry $(4, \underline{34}, \underline{38})$, thin-layer chromatography $(1,33)$, and trace elemental analysis $(1,9,14,38)$. Of these techniques, infrared spectral analysis has probably been the most extensively investigated. In general, such analysis involves a detailed comparison of selected

1. Research chemist.

a Project leader:

3 Underlined numbers in parentheses refer to items in the list of references at the end of this report. 
absorbance bands or ratios of absorbance bands between an unknown oil and a possible reference suspect oil or oils. The most probable suspect oil is that whose absorbance bands most closely coincide with those measured on the actual spilled sample. Various statistical methods $(23,27)$ and, recently, pattern-recognition techniques $(11,36)$ have been incorporated into the absorbance band analysis to improve both the capability and reliability of fingerprinting.

In the absence of weathering processes such as evaporation, emulsification, photooxidation, and biodegradation, a relatively high degree of fingerprinting reliability is obtainable with IR analysis. However, since the chemical and physical changes which accompany weathering markedly alter the magnitude of the IR absorbance bands, the reliability of directly matching a weathered crude oil sample to the correct unweathered crude oil using absorbance data is not as high as that obtained by comparison of unweathered crude oils to crude oil suspects. Although, artificial weathering of all suspect samples constitutes a possible solution to the problem and has been incorporated successfully into some oil identification programs $(3,6)$, the environmental conditions are difficult to simulate identically in the laboratory. However, since the evaporation weathering process produces the greatest alteration in the characteristics of crude oils $(3,5,13)$, artificial weathering of crude oil samples by distillation to approximately $275^{\circ} \mathrm{C}$ has been adopted for several oil identification programs $(1,10,24,38)$. Such artificial weathering has been incorporated into the Bartlesville Energy Research Center program owing to the availability of physical-property data for approximately 9,000 foreign and domestic crude oils including data on the corresponding distillate fractions $\left(-275^{\circ} \mathrm{C}\right)$. This open file constitutes an important bank of data on crude oils and corresponding artificially weathered crude oil samples for oil identification.

This investigation of some problems inherently associated with oil identification by use of infrared spectrometry, should aid in the improvement of IR analysis. This work included a detailed statistical evaluation of frequencies important both to the fingerprinting of crude oils and weathered crude oil samples and an investigation into the magnitude of the variations in absorbance bands between crude oils and corresponding weathered crude oil samples. Problems inherent to the comparative analysis of a weathered crude oil sample to both a group of artificially weathered and unweathered suspect oils also were explored.

\section{EXPERIMENTAL}

\section{Crude Oil and Topped Crude Oil Samples}

Fifty-two crude oil samples, representing important domestic and foreign oil producing fields, were supplied by the BERC crude oil analysis group. The geographical coverage of these samples included nine states and six foreign countries. This same group also supplied physical-property data determined by the Bureau of Mines routine method for crude oil analysis (35) and other data relating to the source and age of each oil sample. 
To simulate the evaporation process of weathering, $10 \mathrm{ml}$ of each crude oil sample was distilled under reduced pressure $\left(10 \mathrm{~mm} \mathrm{Hg}\right.$ ) and the residue, boiling above $275^{\circ} \mathrm{C}$ (atm), retained for subsequent analysis. Gas liquid chromatographic analysis of each topped sample verified the initial boiling point of each sample to be approximately $275^{\circ} \mathrm{C}$. Gasliquid chromatograms were recorded on a Hewlett-Packard model 5830A chromatograph ${ }^{4}$ equipped with a model 18850A integrator (microprocessor). All chromatograms were obtained by use of dual stainless steel columns ( $10 \mathrm{ft}$ by $1 / 8$, in) containing 3 percent OV-1 on acid-washed Chromosorb G (80/100 mesh) and helium as a carrier gas $(20 \mathrm{ml} / \mathrm{min})$. The GC oven was maintained at $50^{\circ} \mathrm{C}$ for 2 minutes after injection and temperature programmed from $50^{\circ}$ to $350^{\circ} \mathrm{C}$ at $5^{\circ}$ per minute. A paper on the detailed comparison of the normaland iso-paraffin distributions for these crude oils and corresponding topped crude oil samples will be published later.

\section{Infrared Analysis}

Infrared spectra were recorded from 4,000 to $650 \mathrm{~cm}^{-1}$ for each crude oil sample and corresponding topped sample on a Perkin-Elmer model 283 spectrophotometer by use of $0.10 \mathrm{~mm}$, fixed-pathlength, sealed, sodium chloride sample cells. Although sealed sample cells are difficult to use with viscous samples, such usage does reduce the variations in sample thickness associated with other sample cells. Highly viscous samples were heated slightly to facilitate introduction into the sample cell with a glass syringe. The Barnes Engineering cells used required approximately $0.4 \mathrm{ml}$ of sample. Care was maintained to clean and dry the sample cells thoroughly with carbon disulfide and filtered-anhydrous air between samples. All spectra were recorded as "neat" (undiluted) samples.

To obtain analytical uncertainty data, spectra were recorded in triplicate for selected samples. In such an analysis, the sample cell was filled with the sample, the spectrum was recorded, the cell was thoroughly cleaned, and the sample was reintroduced into the cell. For each spectra, the transmission data at frequencies considered to be of importance in the fingerprinting of crude oils were obtained, converted to absorbance data, and tabulated. To simplify analysis, a 100 percent transmission base line was used to obtain transmission data from all spectra.

\section{RESULTS AND DISCUSSION}

\section{Oil Samples}

Table 1 presents source data for the analyzed crude oils (state or country and field) including geological formation or age and BERC identification number.

\footnotetext{
${ }^{4}$ Reference to specific brands of equipment is made for identification only and does not imply endorsement by ERDA.
} 
TABLE 1. - Source data for analyzed crude oils

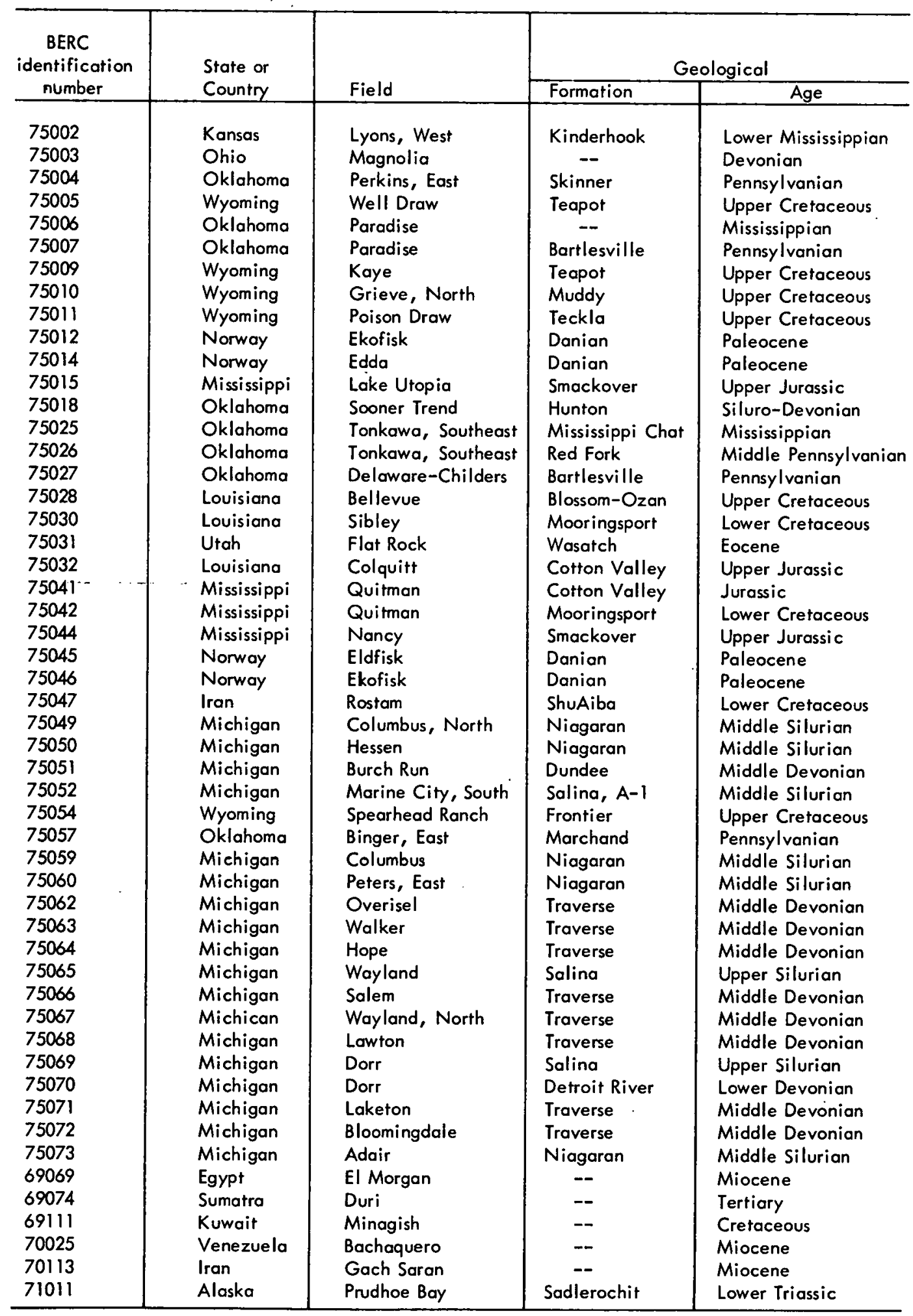


The use of 15 Michigan crude oils provided a basis for investigating the possible selective identification of crude oils from a common geographic origin and common geological formation or age.

Various processes are known to combine and alter the characteristics of oil during exposure at sea $(13,15)$. These processes include evaporation, emulsification, photooxidation, and biodegradation. Naturally, environmental conditions and the length of exposure regulate the degree of variation. Efforts have been made to incorporate the weathering phenomena into oil-identification programs. These have involved both the fundamental investigations of the weathering processes for predictive purposes $(13,24)$ and the simulated weathering of suspect samples for analytical analysis $(3,6,38)$. Most researchers agree that the evaporation process constitutes the greatest single effect upon crude oils and related materials, and such evaporation can be easily simulated by distillation $(1,10,18,24,38)$. Thus, samples of the crude oils listed in table 1 were distilled through $275^{\circ} \mathrm{C}$ and the resultant residues analyzed. Distillation to this temperature represents severe evaporative weathering of the crude oil and is consistent with the loss of normal paraffins through $C_{15}$. Although not as elaborate as other modes of artificial weathering, as a first approximation, distillation yields a good estimate of a weathered sample and can be accomplished rapidly with little equipment cost. It should be noted that "partially" weathered spilled samples could be distilled to this temperature for a better comparison with artificially weathered reference crude oils.

\section{Selection of Important Analytical IR Frequencies}

The selection of frequencies most beneficial to the identification and/or fingerprinting of crude oil samples and related material is of major importance. As shown in table 2, absorption bands occurring between the regions of 1700 and $650 \mathrm{~cm}^{-1}$ have generally been recognized to be most important to oil identification $(22,25-26,36)$. However, the number of bands considered to be required or used for fingerprinting varies from 7 to 21 $(22,25-26,36)$. Although many frequencies can be used in such analysis through the use of computers, the most simple analysis, employing the optimal minimum number of frequencies which will accomplish the desired selectivity, should be used.

Mattson and Spencer (36) have suggested and demonstrated that the analytical error associated with the absorbance at each frequency should be considered when establishing a set of selective frequencies for crude oil fingerprinting. The frequencies used in this study were selected initially based upon the repeated occurrence of distinct absorbances at these frequencies in the crude oil sample analysis. The use of distinct absorbance bands--that is, peaks--circumvents the problems associated with the variation of peak maxima among various oil samples. Hence, no emphasis was placed upon determining the exact frequencies associated with the peak maxima. Therefore, frequencies referred to should be considered to correspond to absorption bands occurring at or approximately at the given frequency. For the crude oil samples investigated, the occurrence of distinct bands at all 14 initially selected frequencies is 82 percent. With the exclusion 
of the absorption band at $670 \mathrm{~cm}^{-1}$, the occurrence of distinct bands is essentially 100 percent. Figure 1 illustrates typical IR transmission spectra for two crude oil samples and denotes those frequencies most important for oil identification.

TABLE 2. - Frequencies used in oil identification

\begin{tabular}{cccc}
$\begin{array}{c}\text { Kawahara (22) } \\
\mathrm{cm}^{-1}\end{array}$ & $\begin{array}{c}\text { Matfson(26) } \\
\mathrm{cm}^{-1}\end{array}$ & $\begin{array}{r}\text { Lynch and Brown (25) } \\
\mathrm{cm}^{-1}\end{array}$ & $\begin{array}{c}\text { Spencer (36) } \\
\mathrm{cm}^{-1}-\end{array}$ \\
\hline-- & 1694 & -- & -- \\
1600 & 1600 & -- & 1604 \\
1460 & 1456 & -- & -- \\
1375 & 1375 & -- & 1376 \\
-- & 1309 & -- & 1306 \\
-- & 1168 & 1160 & 1165 \\
-- & -- & 1145 & -- \\
-- & -- & 1070 & -- \\
1027 & 1034 & 1020 & 1033 \\
-- & -- & 955 & 963 \\
-- & -- & 915 & -- \\
-- & -- & 890 & -- \\
870 & 874 & 870 & -- \\
-- & -- & 845 & 847 \\
-- & -- & 835 & -- \\
-- & -- & 820 & -- \\
810 & 814 & 805,810 & 810 \\
-- & -- & 790 & -- \\
-- & -- & 780 & -- \\
-- & -- & 765,770 & 766 \\
-- & 747 & 740 & 743 \\
720 & 725 & 720,725 & 723 \\
-- & -- & 695 & 698 \\
& & & \\
\hline & & &
\end{tabular}

To further investigate the 14 initially selected frequencies, the analytical and population standard deviations in the associated absorbance bands were determined for the population of crude oil samples. The ratio of the percent standard deviation in the absorbances for the population to the analytical percent standard deviation was used as the criteria for determining those frequencies most useful for fingerprinting. Table 3 presents the 14 initially selected frequencies, associated average absorbance values, analytical and population percent standard derivations (percent $\sigma$ anal and percent $\sigma$ pop, respectively), and the ratio of percent $\sigma$ pop to percent $\sigma$ anal obtained from IR spectral analysis of the 52 crude oil samples. With the possible exception of the band at $1375 \mathrm{~cm}^{-1}$ (percent $\sigma \mathrm{pop} /$ percent $\sigma$ anal $=2.34$ ), all bands initially selected are considered to be useful for 


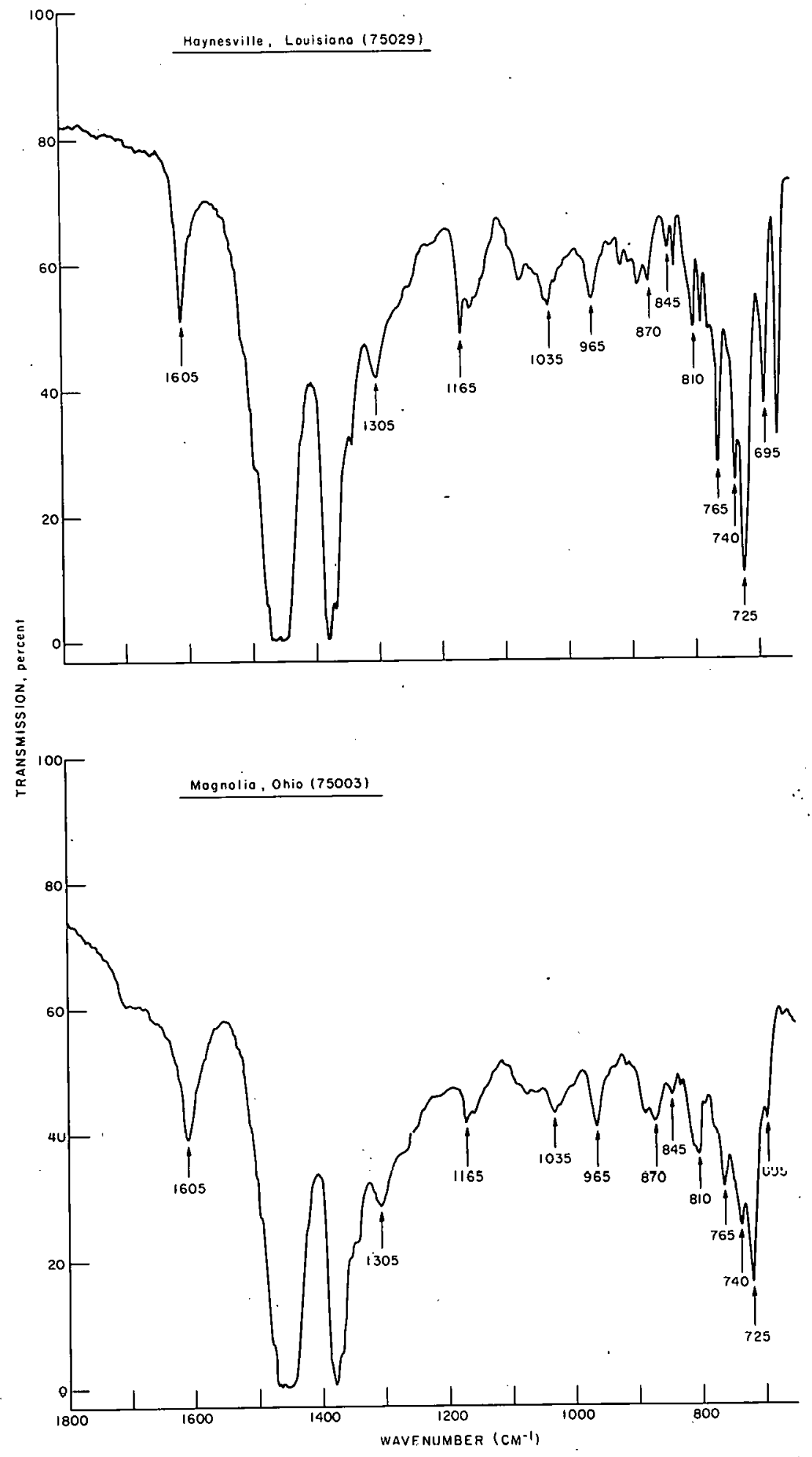

FIGURE 1. - Infrared transmission spectra for Hayneville, Lovisiana (75029) and Magnolia, Ohio (75003) crude oils 
oil identification. These results, representing data solely from crude oils, are in good agreement with those obtained by Spencer (36), whose work was based upon a population of samples including lube oils, No. 2 fuel oils, No. 4 fuel oils, No. 5 fuel oils, and No. 6 fuel oils as well as crude oil samples.

As shown by Wilson (38) and Ahmadjian (3), comparison of IR spectra of weathered crude oil samples to the respective original crude oils shows pronounced changes in the magnitude of absorbance bands at most frequencies. However, due to the large variation among crude oil samples, a detailed investigation into the magnitude of the change has

TABLE 3. - Evaluation of IR frequencies for fingerprinting crude oils

\begin{tabular}{ccccc}
\hline $\begin{array}{c}\text { Frequency, } \\
\mathrm{cm}^{-1}\end{array}$ & $\begin{array}{c}\text { Average } \\
\text { absorbance }\end{array}$ & $\begin{array}{c}\text { Percent } \\
\sigma \text { pop }\end{array}$ & $\begin{array}{r}\text { Percent } \\
\sigma \text { anal }\end{array}$ & $\begin{array}{c}\text { Percent } \sigma \text { pop } \\
\text { percent } \sigma \text { anal }\end{array}$ \\
\hline & & & & \\
1605 & 0.3715 & 16.53 & 0.60 & 27.55 \\
1375 & 2.3042 & 7.79 & 3.33 & 2.34 \\
1305 & 0.4882 & 11.71 & 0.27 & 43.37 \\
1165 & 0.3582 & 10.95 & 0.64 & 17.11 \\
1035 & 0.3418 & 13.04 & 0.39 & 33.44 \\
965 & 0.3199 & 9.00 & 0.70 & 12.86 \\
870 & 0.3466 & 13.31 & 0.38 & 35.03 \\
845 & 0.2937 & 12.98 & 0.61 & 21.28 \\
810 & 0.4457 & 20.82 & 0.52 & 40.04 \\
765 & 0.4987 & 15.48 & 0.60 & 25.80 \\
740 & 0.6113 & 14.96 & 0.45 & 33.24 \\
725 & 0.7664 & 15.61 & 0.67 & 23.30 \\
695 & 0.3488 & 20.46 & 0.65 & 31.48 \\
670 & 0.2800 & 45.43 & 0.90 & 50.48 \\
& & & & \\
\hline
\end{tabular}

little, if any, predictive value. However, these changes can influence decision making concerning frequencies to be used for the fingerprinting of oils. For example, weathering can alter the absorbance at a given frequency until the population variation ( $\sigma$ pop) for that frequency decreases such that the band is of little importance in fingerprinting. To investigate this possibility, an analogous analysis of the topped crude oil samples was made. The resultant average absorbances, percent $\sigma$ pop, and ratio of percent $\sigma$ pop to percent $\sigma$ anal for the 52 topped crude oil samples are given in table 4. Based upon the results obtained on the crude oil samples (see table 3), the band at $1375 \mathrm{~cm}^{-1}$ was not considered. Also, the band at $670 \mathrm{~cm}^{-1}$ was eliminated because of its absence in the topped crude oil spectra. Comparison of the data in table 3 to those in table 4, demonstrates that although significant changes in absorbances at a given frequency occur upon weathering, the frequencies important in the identification of crude oils, are equally important in the 
identification of strongly weathered (topped) crude oils. This has definite pragmatic consequences when a weathered crude oil must be compared to unweathered crude oil suspects.

TABLE 4: - Evaluation of IR frequencies for fingerprinting topped crude oils

\begin{tabular}{cccc}
\hline $\begin{array}{c}\text { Frequency, } \\
\mathrm{cm}^{-1}\end{array}$ & $\begin{array}{c}\text { Average } \\
\text { absorbance }\end{array}$ & $\begin{array}{c}\text { Percent } \\
\sigma \text { pop }\end{array}$ & $\begin{array}{c}\text { Percent } \sigma \text { pop } \\
\text { percent } \sigma \text { anal }\end{array}$ \\
\hline 1605 & 0.3949 & 17.62 & 29.36 \\
1305 & 0.5614 & 9.64 & 35.70 \\
1165 & 0.3635 & 12.05 & 18.83 \\
1035 & 0.3649 & 13.84 & 35.49 \\
965 & 0.2947 & 12.69 & 18.13 \\
870 & 0.3948 & 14.21 & 37.39 \\
845 & 0.3254 & 13.64 & 22.36 \\
810 & 0.5060 & 17.19 & 33.06 \\
765 & 0.4290 & 15.17 & 25.28 \\
740 & 0.5662 & 13.16 & 29.24 \\
725 & 0.7351 & 9.96 & 14.87 \\
695 & 0.2622 & 9.27 & 14.26 \\
\hline
\end{tabular}

As discussed previously, a detailed investigation of the magnitude of the variation in absorbance values between weathered and unweathered crude oil samples has little, if any, predictive value. However, if a weathered spilled oil must be compared to a group of possible unweathered suspect oils, the average magnitude of the variation in absorbance values at each frequency is important. For example, since the most probable suspect oil is that whose absorbance bands most closely coincide with the actual spilled sample, an estimate of the magnitude of the variation in the absorbance values at each frequency between crude oils and corresponding weathered samples should be incorporated into the identification process. Techniques involving a direct comparison of absorbance data between a spilled oil and possible suspect oils usually consider variations in absorbances from 5 to 50 percent $(3,25)$. Commonly, absorbance bands with agreement better than 10 percent are used for confirmation.

To investigate the variation in absorbance bands between a crude oil sample and the corresponding weathered (topped) sample as a function of frequency, the percent deviations ( $A$ weathered $-A_{\text {crude }} \times 100$ ) between the crude and corresponding topped A crude

sample at the 12 key frequencies were determined. Table 5 presents the average percent deviations and associated standard deviations for 46 pairs of crude oil and topped samples. 
The data show that absorbances at $965,765,740,725$, and $695 \mathrm{~cm}^{-1}$ generally decrease between the crude and the topped sample and increase at the remaining seven frequencies However, as expected, the variation among pairs is very large, as demonstrated by the magnitude of the standard deviations. Consequently, although the data may suggest the presence of trends between weathered and unweathered crude oil samples, the uncertainty precludes any a priori predictions. It is important to note, however, that on

TABLE 5. - Variations in IR absorbances between crude oils and corresponding topped crude oil samples

\begin{tabular}{ccc}
\hline $\begin{array}{c}\text { Frequency } \\
\mathrm{cm}^{-1}\end{array}$ & $\begin{array}{c}\text { Average percent } \\
\text { deviation }\end{array}$ & $\begin{array}{c}\sigma \text { average } \\
\text { percent deviation }\end{array}$ \\
\hline & 5.5 & 14.7 \\
1305 & 13.5 & 5.5 \\
1165 & 0.9 & 6.8 \\
1035 & 5.5 & 10.7 \\
965 & -8.8 & 8.8 \\
870 & 11.8 & 9.3 \\
845 & 7.9 & 12.0 \\
810 & 12.8 & 16.2 \\
765 & -12.3 & 15.0 \\
740 & -6.2 & 13.0 \\
725 & -2.1 & 11.5 \\
695 & -20.9 & 14.7 \\
\hline
\end{tabular}

the average, absorbance bands between weathered and unweathered samples differ between 1 and 21 percent for the frequencies and samples investigated. For the 12 frequencies and crude oil pairs investigated, the average of the average percent deviations (column 2) is 9.0 percent. These data suggest that weathering alone can account for variations in absorbance bánds between actually spilled and suspect samples of approximately 9 percent on the average and that differences as large as 21 percent did occur for one of the frequencies $\left(695 \mathrm{~cm}^{-1}\right)$. These data further show that absorbance bands at some frequencies vary much less than at others. Hence, in those cases in which a weathered oil is compared to a group of suspect unweathered oils, emphasis should be placed on those frequencies whose absorbance bands are less affected by weathering. In the present study, these frequencies include absorbance bands at 1605, 1165, 1035, $965,845,740$, and $725 \mathrm{~cm}^{-1}$. However, as noted above, a large variation in absorbances may be expected at these frequencies between weathered and unweathered samples as demonstrated by the large standard deviations. 


\section{Selective Identification of Similar Crude Oils}

Various techniques have been investigated in which infrared spectroscopy was used in the identification of crude oil and related materials $(3,20,25,26,36)$. These techniques predominantly entail a detailed comparison of selected absorbance bands or ratios of absorbance bands between unknown and suspect oil samples. Various statistical methods $(23,27)$ and, recently, pattern-recognition techniques $(11,36)$ have been included in such analyses to improve both the capability and reliability of fingerprinting and/or classification. However, regardless of the technique used, the reliability of identification depends upon the uniqueness of the actual spilled oil. To investigate further the uniqueness of crude oils, 15 crude oil samples and corresponding weathered samples from the same general geographic region were analyzed. Samples representing six counties in Michigan were produced from three geological formations corresponding to three different geological ages. Although crude oil samples from various locations around the world may be similar, samples from the same geographical location and geological formation or age should be very similar and, hence, difficult to differentiate. These samples also were analyzed to investigate whether suspect samples should be artificially weathered before analysis or whether the direct comparison of a weathered sample to spectrally similar unweathered suspect samples can be reliably used for fingerprinting. Owing to the simplicity of the technique, a modification of the absorptivity ratio method described by Lynch and Brown (25) was used for the comparative analysis. Since, in the present case, the sample thickness for each spectra was identical, the ratio of the absorbance at each frequency for each suspect oil to the absorbance for the spilled oil at the corresponding frequency was compared to one and the percent difference tabulated. Equation 1 was used:

$$
\left(\frac{A_{i}}{A_{i}}-1.0\right) 100=\text { percent Diffi }
$$

where $A_{i}$ and $A_{i}$ correspond to the absorbance bands for the $i^{\text {th }}$ frequency for a reference suspect crude oil and the spilled oil, respectively.

Assuming the crude oil designated as 75066 to represent a spilled sample, the number of absorbance band ratios at the 12 selected frequencies for each suspect crude oil which differed by less than $5,10,15,20,25,30$, and 50 percent from the suspect sample were obtained using equation 1 . The results are presented in table 6 . The unweathered spill sample (75066) was chosen because its absorbance values at the selected frequencies closely approximate the average absorbance value at each frequency for the population of suspect oils. Consequently, this sample represents the "average" crude oil sample in the population. As seen in table 6, since the analytical error associated with the absorbance band at each frequency is less than 1 percent (see table 3), all absorbance bands differ by less than 5 percent for sample 75066, and it is uniquely identified as the most probable suspect oil. However, samples 75063 and 75071 also match reasonably well with the spilled unweathered oil. Close inspection of the data in table 6 also suggests the presence of a trend between the geological producing formation or age. The lower eight 
crude oil samples in table 6 represent samples from the same Traverse geological formation and middle Devonian age. In contrast, the remaining seven samples represent other geological formations or age (see table 1). To investigate this possible trend further, 75059 was assumed to be the spilled oil and the analogous analysis made. The results are given in table 7 . Again the correct suspect oil is identified; however, the

TABLE 6. - Comparison of absorbance bands for crude oil 75066 to suspect crude oil samples

\begin{tabular}{cccccccc}
\hline $\begin{array}{c}\text { Identification } \\
\text { number }\end{array}$ & \multicolumn{7}{c}{ Number of absorbance bands differing less than } \\
\cline { 2 - 8 } & 5 pct & 10 pct & 15 pct & 20 pct & 25 pct & 30 pct & 50 pct \\
\hline 75049 & 1 & 4 & 7 & 8 & 10 & 11 & 12 \\
75050 & 3 & 4 & 4 & 5 & 6 & 9 & 11 \\
75059 & 0 & 4 & 6 & 7 & 7 & 9 & 11 \\
75060 & 0 & 6 & 7 & 10 & 11 & 11 & 12 \\
75052 & 2 & 3 & 6 & 7 & 10 & 11 & 12 \\
75065 & 3 & 4 & 4 & 9 & 11 & 11 & 12 \\
75069 & 2 & 4 & 5 & 8 & 11 & 11 & 12 \\
75062 & 3 & 10 & 11 & 12 & & & \\
75063 & 10 & 12 & & & & & \\
75064 & 2 & 7 & 9 & 12 & & & \\
75066 & 12 & & & & & & \\
76067 & 2 & 6 & 8 & 12 & & & \\
76068 & 5 & 10 & 12 & & & & \\
75071 & 7 & 12 & & & & & \\
75072 & 4 & 10 & 12 & & & & \\
& & 10 & 72 & & & &
\end{tabular}

relationship between formation or age is not as evident. Clearly, the lower eight crude oil samples are not similar to the others. The remaining seven suspects correspond to the Salina and Niagaran formations of the Silurian age. Thus, crude oils produced from the Traverse formation are unique to those oils produced from either the Salina (samples: 75052, 75065, and 75069) or Niagaran formations (samples: 75049, 75050, 75059, and 75060); however, the samples from the latter two formations are not unique. From the available data, it is not possible to discem whether these relationships can be used for predictive purposes. However, the data in tables 6 and 7 do suggest that crude oils from the same geographical location are distinguishable by IR analysis and that relationships do exist between the geological formations or ages of crude oils.

Various research groups have shown that crude oil samples can be artificially weathered in the laboratory to give good estimates of actual weathered crude oils samples $(3,6,38)$. To investigate problems associated with the comparison of artificially weathered samptes and to ascertain the reliability of fingerprinting a weathered crude oil sample to 
TABLE 7. - Comparison of absorbance bands for crude oil 75059

to suspect crude oil samples

\begin{tabular}{|c|c|c|c|c|c|c|c|}
\hline \multirow{2}{*}{$\begin{array}{c}\begin{array}{c}\text { Identification } \\
\text { number }\end{array} \\
\end{array}$} & \multicolumn{7}{|c|}{ Number of absorbance bands differing less than } \\
\hline & $5 \mathrm{pct}$ & 10 pct & I5 pct & $20 \mathrm{pct}$ & $25 \mathrm{pct}$ & $30 \mathrm{pct}$ & $50 \mathrm{pct}$ \\
\hline 75049 & 8 & 11 & 12 & & & & \\
\hline 75050 & 7 & 11 & 12 & & & & \\
\hline 75059 & 12 & & & & & & \\
\hline$\overline{75060}$ & 7 & 10 & 11 & 11 & 12 & & \\
\hline 75052 & 9 & 12 & & & & & \\
\hline 75065 & 2 & 3 & 5 & 6 & 10 & 11 & 12 \\
\hline 75069 & 5 & 9 & 12 & & & & \\
\hline 75062 & 4 & 5 & 5 & 7 & 7 & 9 & 12 \\
\hline 75063 & 2 & 3 & 5 & 8 & 10 & 11 & 12 \\
\hline 75064 & 5 & 5 & 5 & 7 & 7 & 7 & 12 \\
\hline 75066 & 0 & 4 & 6 & 7 & 10 & 11 & 12 \\
\hline 75067 & 3 & 4 & 5 & 7 & 7 & 7 & 12 \\
\hline 75068 & 3 & 3 & 4 & 7 & 7 & 9 & 12 \\
\hline 75071 & 2 & 4 & 4 & 7 & 8 & 11 & 12 \\
\hline 75072 & 2 & 4 & 4 & 7 & 7 & 10 & 12 \\
\hline
\end{tabular}

unweathered suspect samples, a topped crude oil sample (75066) was compared to a group of topped suspect samples and to the original crude (unweathered) samples. The results are presented in tables 8 and 9, respectively. Comparison of tables 6 and 8 shows that, based on IR analysis, the topped samples are not as unique as are the crude oil samples. In fact, there is a pronounced "I leveling effect" in that the variance in the absorbance bands for this population of topped samples decreases markedly. Furthermore, table 8 shows that within a 5-percent difference limit, samples 75066, the correct suspect, and 75072 are indistinguishable. Within a 10-percent limit, all absorbances for an additional three suspect oils are included. However, it is important to note that crude oil samples 75066 can be differentiated from 75072 upon closer inspection of the two spectra. Thus, these data suggest that comparison of weathered spilled samples with artificially weathered reference oils. provides a good basis for recognition, but, the procedure for such artificial weathering must be reliably consistent. Even when a consistent and uniform weathering process such as distillation is used topped samples from the same geographical origin are not as uniquely distinguishable as are the corresponding original crude oils. Note also that the trends discussed previously concerning oil-producing formation or age are more difficult to discern for the topped crude oil analysis owing to the "leveling effect." 
TABLE 8. - Comparison of absorbance bands for topped crude oil 75066 to topped suspect crude oil samples

\begin{tabular}{lccccccc}
\hline \multirow{2}{*}{$\begin{array}{c}\text { Identification } \\
\text { number }\end{array}$} & \multicolumn{7}{c}{ Number of absorbance bands differing less than } \\
\cline { 2 - 7 } & $5 \mathrm{pct}$ & 10 pct & 15 pct & 20 pct & 25 pct & 30 pct. & 50 pct \\
\hline 75049 & 7 & 9 & 10 & 11 & 12 & & \\
75050 & 5 & 7 & 11 & 12 & & & \\
75059 & 4 & 9 & 12 & & & & \\
75060 & 6 & 8 & 10 & 12 & & & \\
75052 & 6 & 7 & 9 & 12 & & 11 & 12 \\
75065 & 2 & 4 & 5 & 8 & 11 & & \\
75069 & 5 & 8 & 9 & 11 & 12 & & \\
75062 & 6 & 11 & 12 & & & & \\
75063 & 4 & 11 & 12 & & & & \\
75064 & 9 & 11 & 12 & & & & \\
75066 & 12 & & & & & & \\
75067 & 6 & 12 & & & & & \\
75068 & 3 & 12 & & & & & \\
75071 & 9 & 12 & & & & & \\
75072 & 12 & & & & & & \\
\end{tabular}

The results of the alternative direct comparison of a weathered spilled crude oil sample to a group of unweathered suspect samples are give in table 9. As seen from the data, the correct suspect (75066) is not reliably distinguishable from the other crude oil samples. For the actual crude oil suspect, a limit of 15 percent is required to encompass all 12 selected absorbance bands, and within a 5-percent limit, this sample would not even be considered as the probable suspect. Considering the small number of absorbance bands differing by less than 5 percent, no improvement is attained by use of those frequencies whose ahsorbances change by a small amount (see previous discussion). In light of the large variations in absorbance data between the crude oil samples and associated topped samples (table 5) and the results in table 9, suspect samples should be artificially weathered before comparative analysis by use of a reliable and consistent weathering procedure such as distillation to $275^{\circ} \mathrm{C}$. Data comparisons in tables 8 and 9 reinforce the necessity of using a multianalytical approach to oil identification programs.

\section{SUMMARY AND CONCLUSIONS}

Based upon infrared absorbance data at 14 specially selected frequencies for a sample population of 52 crude oils and 52 corresponding topped crude oil samples, statistical analysis was used to obtain a group of 12 frequencies most beneficial for the fingerprinting 
TABLE 9. - Comparison of absorbance bands for topped crude oil 75066 to suspect crude oil samples.

\begin{tabular}{|c|c|c|c|c|c|c|c|}
\hline \multirow{2}{*}{$\begin{array}{c}\text { Identification } \\
\text { number }\end{array}$} & \multicolumn{7}{|c|}{ Number of absorbance bands differing less than } \\
\hline & $5 \mathrm{pct}$ & $10 \mathrm{pct}$ & $15 \mathrm{pct}$ & 20 pct & $25 \mathrm{pct}$ & $30 \mathrm{pct}$ & $50 \mathrm{pct}$ \\
\hline 75049 & 2 & 4 & 7 & 8 & 10 & 10 & 12 \\
\hline 75050 & 0 & 3 & 7 & 8 & 10 & 10 & 11 \\
\hline 75059 & 1 & 2 & 7 & 9 & 9 & 9 & 11 \\
\hline 75060 & 3 & 4 & 7 & 10 & 10 & 10 & 11 \\
\hline 75052 & 1 & 3 & 6 & 10 & 10 & 10 & 11 \\
\hline 75065 & 1 & 8 & 9 & 9 & 10 & 11 & 12 \\
\hline 75069 & 0 & 5 & 8 & 10 & 10 & 10 & 12 \\
\hline 75062 & 4 & 6 & 9 & 12 & & & \\
\hline 75063 & 2 & 6 & 11 & 12 & & & \\
\hline 75064 & 1 & 5 & 9 & 11 & 12 & & \\
\hline 75066 & 1 & 9 & 12 & & & & \\
\hline 75067 & 1 & 1 & 7 & 9 & 12 & & \\
\hline 75068 & 2 & 6 & 9 & 12 & & & \\
\hline 75071 & 2 & 6 & 9 & 12 & & & \\
\hline 75072 & 2 & 5 & 9 & 12 & & & \\
\hline
\end{tabular}

of crude oils and related materials. The resultant 12 absorbance bands, considered to be of importance for crude oils, are also important for the identification of weathered (topped) crude oil samples. This has definite pragmatic consequences when a weathered crude oil must be compared to unweathered crude oil suspects.

Although a detailed investigation of the magnitude of the variation in absorbance values between weathered and unweathered crude oil samples has little predictive value, such studies are necessary for direct comparative analysis of weathered spilled oils to unweathered crude oil suspects. Based upon 46 pairs of crude and corresponding topped crude oil samples, comparison of the absorbance bands between the crude oils and topped samples indicate that absorbances generally decrease at 965,765,740,725, and $695 \mathrm{~cm}^{-1}$ and increase at $1605,1305,1165,1035,870,845$, and $810 \mathrm{~cm}^{-1}$. For these frequencies and samples investigated, absorbance bands vary on the average from 1 to 21 percent upon weathering. For the 12 frequencies studied, the average variation in the absorbance bands is approximately 9.0 percent. Hence, in a comparative analysis procedure involving the matching of a spilled weathered oil sample to a group of unweathered suspects, variations in absorbance values owing to weathering alone will average 9 percent and such factors should be incorporated into the comparative technique. As expected, although trends in absorbance values may exist between weathered and unweathered crude oil 
samples, the uncertainty precludes assessment of these trends for predictive value. However, absorbances at 1605, 1165, 1035, 965, 845, 740, and $725 \mathrm{~cm}^{-1}$ do appear to be affected less by severe weathering.

Identification of spilled unknown crude oils or related materials, generally, entails a detailed comparison of selected absorbance bands or ratios of absorbances bands between unknown and suspect oil samples. Inherently, the reliability of such an analysis depends upon the uniqueness of the actual spilled oil. To investigate further the uniqueness of crude oils, 15 crude oil samples and corresponding topped samples from the same geographical location were comparatively analyzed by a modification of the absorptivity ratio method described by Lynch and Brown (25).

These samples were also analyzed to investigate whether suspect samples should be artificially weathered before analysis or whether the direct comparison of weathered sample to spectrally-similar unweathered suspect samples can be used for reliable identification. Results show that a spilled unweathered crude oil can be identified from a group of suspect crude oils from the same general geographical location. Also, results suggest that trends exist between the geological producing formation or age. A special look at 15 crude oil samples, assumed to constitute the suspect set, established that crude oils from either the same producing formation or age are more difficult to distinguish than those samples representing different geological formations or ages. Comparative IR analysis among topped crude oil samples shows that the topped samples are not as unique as are the corresponding crude oil samples because of a marked decrease in the variance in absorbance bands at each frequency for a given population of suspect samples. These data suggest that comparison of weathered samples with weathered reference oils provide a good basis for recognition; but the procedure for such artificial weathering needs to be reliably consistent. The results of the alternative direct comparison of a weathered spilled crude oil to a group of unweathered suspect samples show that for spectrally similar crude oil samples, the correct suspect is not reliably matched to the spilled oil based on IR analysis. Consequently, suspect oil samples should be artificially weathered before comparative analysis by use of a reliable and consistent weathering procedure such as distillation to $275^{\circ} \mathrm{C}$. Frequently when the spilled oil is not severely weathered, a more reliable match may also be obtained by artificially weathering both spilled and reference oils before analysis. Results of both the comparative analyses of a weathered crude oil to either weathered and unweathered suspect crude oil samples reinforce the necessity of using a multianalytical approach to oil identification programs.

\section{ACKNOWLEDGMENTS}

We thank J. L. Lacina and D. T. Nichols for supplying crude oil samples and physicalproperty data and J. A. Sears for obtaining infrared spectra. All are employees of the Bartlesville Energy Research Center. 


\section{REFERENCES}

1. Adlard, E. R. A Review of the Methods for the Identification of Persistent Hydrocarbon Pollutants on Seas and Beaches. J. Inst. Petrol., v. 58, No. 560, March 1972, pp. 63-74.

2. Adlard, E. R., L. F. Creaser, and P. H. D. Matthews. Identification of Hydrocarbon Pollutants on Seas and Beaches by Gas Chromatography. Anal. Chem., v. 44, No. 1, January 1972, pp. 64-73.

3. Ahmadiian, M., C. D. Baer, P. F. Lynch, and C. W. Brown. Infrared Spectra of Petroleum Weathered Naturally and Under Simulated Conditions. Environ. Sci. and Technol., v. 10, No. 8, August 1976, pp. 777-781.

4. Anbar, M., A. C. Scott, and M. E. Scolnick. Identification of Oil Spills and Determination of Duration of Weathering by Field lonization Mass Spectrometry. 1974 Pittsburgh Conference on Analytical Chemistry and Applied Spectroscopy, March 4-8, 1974, Cleveland, Ohio, paper 224.

5. Bentz, A. P. Oil Spill Identification. Anal. Chem., v. 48, No. 6, May 1976, pp. 455A-470A.

6. Brown, C. W. and P. F. Lynch. Infrared Analysis of Weathered Petroleum Using Vacuum Techniques. Anal. Chem., v. 48, No. 1, January 1976, pp. 191-195.

7. Brown, C. W., P. F. Lynch, and M. Ahmadiian. Applications of Infrared Spectroscopy in Petroleum Analysis and Oil Spill Identification. Appl. Spectrosc. Rev., v. 9, No. 2, 1975, pp. 223-248.

8. Brown, C. W., P. F. Lynch, and M. Ahmadiian. Monitoring Narragansett Bay Oil Spills by Infrared Spectroscopy. Environ. Sci. and Technol., v. 8, July 1974, pp. 669-670.

9. Brunnock, J. V., D. F. Duckworth, and G. G. Stephens. Analysis of Beach Polllutants, J. Inst. Petrol., v. 54, No. 539, November 1968, pp. 310-325.

10. Chisholm, B. R., H. G. Eldering, L. P. Giering, and A. W. Hornig. Total Luminescence Contour Spectra of Six Topped Crude Oils. ERDA BERC $\mathrm{RI}-76 / 16,1976,42 \mathrm{pp}$. 
11. Clark, H. A. and D. C. Jurs. Studies of Petroleum Sample Identification Using Pattern Recognition Techniques. 1976 Pittsburgh Conference on Analytical Chemistry and Applied Spectroscopy, March 1-5, 1976, Cleveland, Ohio, paper 325.

12. Cole, R. D. Recognition of Crude Oils by Capillary Gas Chromatography. Nature, v. 233, October 1971, pp. 546-548.

13. Davis, S. J. and G. F. Gibbs. The Effect of Weathering on a Crude Oil Residue Exposed at Sea. Water Research, v. 9, 1975, pp. 275-285.

14. Duewer, D. L., B. R. Kowalski, and T. F. Schatzki. Source Identification of Oil Spills by Pattern Recognition Analysis of Natural Elemental

Composition. Anal. Chem., v. 47; No. 9, August 1975, pp. 1574-1583.

15. Freegarde, M., C. G. Hatchard, and C. A. Parker. Oil Spill at Sea: Its Identification, Determination, and Ultimate Fate. Lab. Pract., v. 20, No. 1, 1971, pp. 35-40.

16. Garza, M. E. and J. Muth. Characterization of Crude, Semirefined and Refined Oils by Gas-Liquid Chromatography. Environ. Sci. and Technol., v. 8, No. 3, March 1974, pp. 249-255.

17. John, P. and I. Soutar. Identification of Crude Oils by Synchronous Excitation Spectrofluorimetry. Anal. Chem., v. 48, No. 3, March 1976, pp. 520524.

18. Journal of the Institute of Petroleum. Analytical Methods for the Identification of the Source of Pollution by Oil of the Seas, Rivers, and Beaches, v. 56, No. 548, March 1970, pp. 107-117.

19. Kawahara, F. K. Characterization and Identification of Spilled Fuel Oils by Gas Chromatography and Infrared Spectrophotometry. J. Chromatogr. Sci., v. 10, October 1972, pp. 629-636.

20. Identification and Differentiation of Heavy Residual Oil and Asphalt Pollutants in Surface Water by Comparative Ratios of Infrared Absorbances. Environ. Sci. and Technol., v. 3, No. 2, February 1969, pp. 150-153.

21. - Trace Organic Components as Fingerprints in Gas Chromatographic Identification of Spilled Asphalts. Environ. Sci. and Technol., v. 10, No. 8, August 1976, pp. 761-765. 
22. Kawahara, F. K. and D. G. Ballinger. Characterization of Oil Slicks on Surface Waters. Ind. Eng. Chem. Prod. Res. Develop., v. 9, No. 4, 1970 , pp. 553-558.

23. Kawahara, F. K., J. F. Santner, and E. C. Julian. Characterization of Heavy Residual Fuel Oils and Asphalts by Infrared Spectrophotometry Using Statistical Discriminant Function Analysis. Anal. Chem., v. 46, No. 2, February 1974, pp. 266-273.

24. Kreider, R. E. Identification of Oil Leaks and Spills. Joint. Conf. Prevention and Control of Oil Spills (A Report of the Western Oil and Gas Association Subcommittee on Analysis of Beach Pollutants), June 15, 1971, Washington, D. C., 26 pp.

25. Lynch, P. F. and' C. W. Brown. Identifying Source of Petroleum by Infrared Spectroscopy. Environ. Sci. and Technol., v. 7, No. 13, December 1973, pp. 1123-1127.

26: Mattson, J. S. "Fingerprinting" of Oil by Infrared Spectrometry. Anal. Chem., v. 43, No. 13, November 1971, pp. 1872-1873.

27. Mattson, J. S. and M. J. Spencer. Multivariate Statistical Approach to the Identification of Oils. 1976 Pittsburgh Conference on Analytical Chemistry and Applied Spectroscopy, March 1-5, 1976, Cleveland, Ohio, paper 326.

28. Parker, C. A. and'W. J. Barnes. Spectrophotofluorimetry of Lubricating Oils: Determination of Oil Mist in Air. Analyst, v. 85, 1960, pp. 3-8.

29. Petrovic, K. and D. Vitorovic. Recognition and Qualitative Characterization of Commercial Petroleum Fuels and Synthetic Fuels by Gas Chromatographic Fingerprinting Technique. J. Chromatogr., v. 119, 1976, pp. 413-422.

30. Pym, J. G., J. E. Ray, G. W. Smith, and E. V. Whitehead. Petroleum Triperpane Fingerprinting of Crude Oils. Anal. Chem., v. 47, No. 9, August 1975, pp. 1617-1622.

31. Ramsdale, S. J. and R. E. Wilkinson. Identification of Petroleum Sources of Beach Pollution by Gas-Liquid Chromatography. J. Inst. Petrol., v. 54, No. 539, November 1968, pp. 326-332.

32. Rasmussen, D. V. Characterization of Oil Spills by Capillary Column Gas Chromatography. Anal. Chem., v. 48, No. 11, September 1976, pp. 1562-1566. 
33. Saner, W. A. and G. E. Fitzgerald II. Thin-Layer Chromatographic Technique for Identification of Waterborne Petroleum Oils. Environ. Sci. and Technol., v. 10, No. 9, September 1976, pp. 893-897.

34. Scolnick, M. E. and M. Anbar. Oil Fingerprint Pattern Identification by Statistical Analysis. 1975 Pittsburgh Conference on Analytical Chemistry and Applied Spectroscopy, March:3-7, 1975, Cleveland, Ohio, paper 401.

35. Smith, N. A. C., H. M. Smith, O. C. Blade, and E. L. Garton. The Bureau of Mines Routine Method for the Analysis of Crude Petroleum. I. The Analytical Method. BuMines Bull. 490, 1951, 82 pp.

36. Spencer, M. J. Oil Identification Using Infrared Spectrometry. Department of Transportation, United States Coast Guard, UM-RSMAS\#7502 (DOT-CG81-75-1364), June 1975, 85 pp.

37. Thruston, A. D. and R. W. Knight. Characterization of Crude and ResidualType Oils by Fluorescence Spectroscopy. Environ. Sci. and Technol., v. 5, No. 1, January 1971, pp. 64-69.

38. Wilson, C. A., E. P. Ferrero, and H. J. Coleman. Crude Oil Spills Research. An Investigation and Evaluation of Analytical Techniques. BuMines RI 8024, 1975,28 pp.

39. Zafiriou, O. C. Improved Method for Characterizing Environmental Hydrocarbons by Gas Chromatography. Anal. Chem., v. 45, No. 6, May 1973, pp. 952-956. 